\title{
POLITICAL CELEBRITIES - A NEW DIMENSION OF POLITICAL LEADERSHIP
}

\author{
by Agnieszka Kasińska-Metryka
}

Political leadership is still a research area requiring the most up-to-date approaches, since, being a constant phenomenon in its essence, it is subject to the processes of form transformation. Throughout history, we can indicate the directions of change of the leadership phenomenon. From tribal communities, where often quasi-political functions were combined with religious functions (based on the charismatic authority of shamans), through the time of statesmen and ideological leadership, we have now arrived at the era of media leaders.

The current model of celebrity leadership (media, marketing leadership) seems to be based on three mainstays, namely:

- Mass media

- The activity of political advisors (experts)

- Public opinion polls (surveys).

The mediatisation of politics is a factor that has fundamentally changed the picture of the political market ${ }^{1}$. Definitions of mediatisation show different aspects of it, but for the purposes of this study a simplified pro-

\footnotetext{
1 Political market understood as existing area of cooperation, competition, confrontation of politics subjects, and the impact of communication on the external environment
} 
posal by T. Meyer has been adopted, who defined the term as "a process in which the mass media colonize politics"2. In practice, this means political entities yielding to media pressure, the adoption of rules imposed by the media, and the political actors' dependence on their presence in the media ("who is not in the media, does not exist"). A more comprehensive approach shows mediatisation of political life as a process of "transformation and modernization of the public sphere and of changes in the behaviour of participants under the influence of two types of media - the traditional media (...) and the new media networks"3.

The phenomenon of mediatisation began in the $1960^{s}$ with the development of mass media (especially television). New techniques of communication $\left(1980^{\mathrm{s}}\right)$ intensified the participation of the media in politics. The Internet has become the equivalent of the ancient agora - creating new areas of electoral participation, redefining the existing perception of political communication. The possibility of the multi-transmission of information, rapid response to a political message, the posting of comments, and the obliterating of distinctions between the traditional roles of sender and receiver, have meant that the Internet has become the fastest tool to gain importance in political interaction ${ }^{4}$. One can predict that, in the future, with the increasing number of Internet users, the process of using it for political purposes will undergo further intensification, and a virtual network of politicians-voters will become condensed.

To summarize this section, it should be stated that the mediatisation of politics has provoked both negative and positive effects. The former include the tabloidisation of politics, the superseding of political discourse by simplified advertising, and the creation of news-makers. The positive effects of increased media participation in political life include faster information flow, and the enforced competitiveness and professionalization of political action. The media confront politicians with expectations,

\footnotetext{
2 T. Meyer, Mediated Politics, Camridge 2002, p. 71.

3 B. Dobek-Ostrowska, Komunikowanie polityczne i publiczne, Warszawa 2006, p. 159.

4 See http://www.krytykapolityczna.pl/REDakcja/Internet-i-polityka-relacja/menuid-75.html, [12.02.2012].
} 
the fulfillment of which allows for the maintaining of public interest and for residence in the memory of potential voters. The symbiotic arrangement with the media requires the politician to be available and willing to cooperate, to talk in an interesting way while restricting his speech to a short formula (called "hundred"), and at the same time be telegenic and able to formulate relevant comments.

At this point, the existence of a reverse phenomenon, i.e. de-mediatisation, should also be indicated. This refers to the specific form of communication that takes place between political actors and the public "over the media" but where the media are no more than a tool for the political actors. In practice, this means a situation where politicians treat the media only as a "communication channel" and they lead their own narrative, regardless of the questions asked by journalists or of the adopted structure of the programme. A similar form of avoidance of difficult and uncomfortable questions from journalists tends to intensify the presence of politicians only in the media that are exceptionally favourable to them, allowing them to spin their own "stories" supported by the comments of a sympathetic journalist conducting the programme.

Another factor contributing to the personalisation of politics and to changes within the leadership tools is the growing role of political advisers. The generic name hides within a number of specific professions, which are considered useful, and sometimes even necessary, for the acquisition of and the implementation of power. As noted by Boguslawa DobekOstrowska, the success of political consulting is a consequence of ongoing system changes. These embrace the transformation of the political party model (from the mass to the electoral), rapid technological development and public broad access to the media, and the commercialization of telecommunication and data transmission techniques ${ }^{5}$. Currently, in addition to internal specialists (members of the party, co-leaders, people connected to the values of the given group), consulting is increasingly dealt with by external and independent experts specializing in narrow fields, and offering their knowledge to different political forces, which they do not identify themselves with in terms of ideology.

5 B. Dobek-Ostrowska, op.cit., p. 289. 
It can be argued that, since the modernisation campaigns, the participation of experts in politics creation has increased, and their scope of performance is crucial not only during the election rivalry, but also during the post-election period. This is due to the need for "public relations" actions on the part of politicians. Among the experts supporting the politicians is a large group of specialists in political communication. It includes not only the spin-doctors, but also speech writers (specialists in writing speeches, in the past called ghost-writers), image-makers (specialists in image), trainers in the field of non-verbal communication, etc. The tasks of the experts include more and more new areas; this fact is related to technological development, and also to increasing competition. As noted by Tomasz Goban-Klas, the task of experts may include, among others, preparing statements for the media, public speaking organization, building and monitoring the image in the network, etc. ${ }^{6}$ Political consulting, which has developed mostly in the United States, now it has spread to other continents, and political consultants have been elevated to the role of co-creators of politics ${ }^{7}$.

The growing influence of political experts is accompanied not only by a decline in the importance of party activists, but also by the limitation of the role of leaders in creating their own image. The paradox of media leadership is that individuals with formal authority have accepted the rules imposed by the media and begun to look for its strengthening in popularity. The paradigm of the $21^{\text {st }}$ century is the identification of popularity with the power of influence. The media leader is recognized, valued, and seen as a major player on the political scene. The price leaders pay for their popularity covers not only the loss of part of the seriousness of the office, but also the necessity to accept the fact that the private sphere of each

\footnotetext{
6 See T. Goban-Klas, Public relations, czyli promocja reputacji. Pojęcia, definicje, uwarunkowania, Warszawa 1997, pp. 27-35.

7 It should be noted that the development of political consulting was more rapid in the USA than in Western Europe. In Europe, politicians longer maintained their influence on the course of elections and independence on how to formulate campaign messages. See R. Wiszniowski, Marketing wyborczy. Studium kampanii wyborczych w systemach prezydenckich i semiprezydenckich (Finlandia, Francja, polska, Stany Zjednoczone), Warszawa-Wrocław 2000, pp. 111-113.
} 
person who is entrusted with a public function is drastically limited. This state of being is apparently to increase the transparency of actions taken, and to provide voters with more complete knowledge about the people they have supported, but in practice this knowledge is not useful for electoral decision-making.

Therefore, the thesis that both politicians and voters let themselves be seduced by the magic of the media seems reasonable. The media evoke an interest in politics at the level of emotion (scandals, affairs, moral threads), and so then it will provide information on the "desired" topics. When a politician, in any place and at any time, may be required to give a public speech, the image assumes a special role.

For the purpose of election campaigns the identity of a politician is reduced in favour of his symbolic profile. This means selecting and displaying several leading features (and biographical events) around which a political message can be built. As we know, only a small part of the content is received through words, hence the large role of nonverbal communication - facial expressions, posture, gesture, proxemics, chronemics, vocalics, etc.

With the development of the media - as noted by SL Popkin - voters were given a new "short cut" and the candidate's integrity came to be evaluated on the grounds of information about his behaviour in private life. Information about the candidate is combined into a single narrative, which must have a main character and the cause and effect structure ${ }^{8}$. Only in the media is such a transfer likely to occur and attract the attention of the audience.

The above changes in the methods of image building and its management affect the party leadership in a particular way. Even in the $1950^{\text {s }}$ the image of the party leaders was strongly associated with the image of the party, and only in the $1970^{\mathrm{s}}$ and $1980^{\mathrm{s}}$ was there a widespread interest in the role of political leadership revealed, stemming from the belief that

8 S.L. Popkin, Spekulujący wyborca; komunikacja u perswazja $w$ kampaniach prezydenckich, [in:] Władza i społeczeństwo, t. 1, selection and ed. by J. Szczupaczyński, Warszawa 1995, pp. 233-246. 
popular leaders have a significant influence on their parties' victory ${ }^{9}$. Currently, the leader's external image is shaped by many different factors, such as party and family milieu, advisors, permanent electorate, political competitors, and the media. The role of the leader itself, however, no matter how limited by the influence of others and the need to adapt political offer to market requirements, remains unquestionable. It is not possible to create a reliable and lasting image of politicians that is isolated from their personality traits, their aptitude, their leadership skills, and their style of administration.

As evidenced by political practice, the optimal way to build an image is to find the common area between the capacity of the leader and the expectations towards him, and then to highlight and enhance these qualities (or skills) that the leader has, and which are in demand. Such a market-based view of policy can lead to a distortion of the essence of leadership and to replacing political leaders with celebrities. A question challenging not only researchers is whether the sinusoid of political culture will reverse its direction and return a due dimension to public life or continue reaching into the private sphere of politicians and placing them in the realms of pop culture ${ }^{10}$.

The answers to this question should be sought in the nature of media activity as well as in the persistent influence of political market research conducted on the quality of its activities. In liberal democracies based on associative communication, surveys are a means of obtaining feedback, and are used to establish understanding between participants in political life. Surveys carried out in a correct manner show the distribution of public opinion on a particular matter at a particular time. According to J. Habermas, through the communication channels available to the public, citizens and other actors of the political system watch each other, work out the forum and, ultimately, the product of the political process ${ }^{11}$.

9 I. Podobas, Public relations jako narzędzie kreowania wizerunku partii politycznych, Warszawa 2011, p. 92.

$10 \mathrm{http} / / /$ www.polityka.pl/kraj/analizy/1502585,1,debata-politycy-w-czasach-tabloidow.read, [12.02.2012].

11 S. Michalczyk, Komunikowanie polityczne. Teoretyczne aspekty procesu, Katowice 2005, p. 157. 
Not all market research is carried out and interpreted correctly - a factor which then can be destructive to the system because it derails the processes of reversible communication. Problems associated with the use of survey results fit primarily into three areas, i.e. irregularities in the conducting of surveys (inappropriate selection of the group, biased questions, etc.), an unreliable interpretation of results, and a way of presenting the survey results in the media. The media sometimes sacrifice workshop accuracy in order to present social preferences in a simplified way.

Election campaigns mean increased market research, but, on the evidence of successive elections, despite the constantly improved techniques, surveys do not always accurately predict results, and politicians themselves use them only for temporary purposes. Threats from the surveys also affect attitudes towards an election. Some researchers favour the fact that the publication of opinion polls can distort the decisionmaking process and influence the outcome of an election where there is an undecided electorate ${ }^{12}$.

With regard to political leaders, the most dangerous situation is when leaders make decisions not in the interest of the public, but on the basis of support or lack of support expressed in the polls. This phenomenon, known as "Democracy Survey", is detrimental to the quality of political action, because it limits politicians' creativity, prevents them from making difficult or long term decisions (even if they are reasonable and justified), and imposes an unjustified flexibility. Susceptibility to the expectations of the electorate presented in the polls is a hallmark of media leadership, and a feature clearly differentiating marketing leaders from statesmen: "The true statesman is the one who knows how to make a difficult but necessary decision, sometimes even contrary to current opinion, as General de Gaulle did when withdrawing from Algeria, against the wishes of those who brought him to power"13.

12 M. Mazur, Marketing polityczny, Studium porównawcze prezydenckich kampanii wyborczych w USA i w Polsce, Warszawa 2007, p. 294.

13 http://www.przk.pl/nr/spoleczenstwo/demokracja_sondazowa.html, [12.02.2012]. 
Knowing the exogenous determinants of contemporary leadership, we may ask ourselves to what extent the media are responsible for creating celebrity-type leaders, and to what extent a new kind of leadership has resulted from social expectations. Viewing the results of research as well as the analysis of the election market provokes the thought that the essence of leadership and the social expectations are fundamentally unchanged.

"When a certain number of creatures' - noted G. le Bon - 'join the group, regardless of whether it will be a crowd of people, or herd of animals, they will instinctively seek to submit to some authority" ${ }^{14}$. The leader of the group is needed to improve its operation, to represent it, to be accountable, to provide security, and, above all, to set goals. In stable political systems (not just democracies), the leadership strengthens the legitimacy of power by means of propaganda or marketing tools, and it takes a crisis to verify the effectiveness of the leadership. When a political system is in danger (be it economic or political, or a crisis in its values or communication, etc.), leaders are somehow "stripped" of media popularity and faced with the necessity to demonstrate their real abilities.

The times in which information is the most valuable and most desirable "commodity" are characterised by the "transactional" and not the "relational" way of building a leader-environment dependence in the sphere of economy and politics. In the past, so called ideological leadership was based on the personality of the leader, but also on strong and trusting relations with the public. The marketing perception of politics that regards political subjects as "products" and confines voters to the role of "buyers" equates in political competition to a "struggle for the target." After obtaining legitimacy of power, politicians continue to communicate with voters (political public relations), but these actions can be compared to "afterpurchase customer care." Their purpose is therefore to develop the capital of social trust in the perspective of the next election, not in an honest debate and joint work on objectives and tools. "Many customers" - MG Hermann notes - "know the leader through devious ways: from hearsay or from the media - that is why their attitude is determined by the public image of this person. Therefore, the main concerns of the leaders are to

14 G. Le Bon, Psychologia tłumu, Warszawa 1998, p. 73. 
properly frame and retouch their public image - it must reflect the needs and expectations of customers and express exactly what the leader wants to pass to them"15.

The conclusion is that the transfer of marketing mechanisms from economy to politics, along with the mediatisation processes, has led to the formation of a style of leadership that is determined by:

- The permanent nature of political competition. The struggle for support in the pre-election period has been complemented by activities within post-election marketing (in-between elections) and political public relations.

- The dominant role of political consultants supporting leaders' operations on many grounds, especially in the field of political communication.

- The staging of leaders' operations, coming from the need to "diversify" their offers compared to those of other actors (directed speech, the use of props, scripts of meetings with voters, etc.).

- A strong personalization of party leadership.

- The assimilation of campaign mechanisms into the parliamentarycabinet systems of solutions used during elections in presidential systems.

- The marketing of leadership activities, such as assuming a managerial style of planning and accounting in politics, and the building of relationships with the public based on the trade model for relations.

- The weakening of the programme polarization between the parties, which causes "the blurring of the alternative of offers" and redefines the role of opposition in political systems ${ }^{16}$.

One can predict that the further development of leadership will be connected with the improvement of electoral behaviour research techniques, including the using of neurobiological tools. Understanding the motives of electorate behaviour on the level of political psychology will

15 M.G. Hermann, Elementy przywództwa, [in:] Władza..., op.cit., p. 309.

16 See R. Herbut, Opozycja polityczna - charakter oraz wzorce rywalizacyjnych zachowań w reżimach demokratycznych, [in:] W kręu historii i politologii. Ksiega jubileuszowa dedykowana profesorowi Stanisławowi Dąbrowskiemu, Wrocław 2002, p. 263. 
enable the wider alignment of political offers with social expectations, and it will encourage the seeking of new forms of effective communication. The involvement of individuals in politics, creating a situation of "coparticipation", for example through virtual political volunteering, will create positive political attitudes towards the objects on the political scene. So, instead of political transactions, we will have re-built relationships. 